\title{
Self care in patients with chronic heart failure. Pilot study - self care includes problems
}

\author{
Renata Halmo ${ }^{a}$, Jan Galuszka ${ }^{b, c}$, Katerina Langova ${ }^{d}$, Dana Galuszkovac
}

\begin{abstract}
Aim. The goal of this pilot study was to define the scope of therapeutic self-care demand in heart failure (HF) patients according to the concepts of self-care postulated by D.E. Orem and to determine the level of problems experienced and self-care in these patients.

Methods. A questionnaire consisting of 7 areas with closed format questions was developed according to the definition. The level of patient problems and level of self-care actions were mapped in each area. The questionnaire was distributed at the hospital outpatient clinic. The study group consisted of 47 heart failure patients (14 women) with following characteristics: average age 68 years, average BMI 29.4, resynchronization therapy $21 \%$, hypertension $69.8 \%$, diabetes mellitus $25.6 \%$, coronary artery disease $46.5 \%$, dilated cardiomyopathy $46.5 \%$, obesity $46.5 \%$, smoking history $39.5 \%$ (present and past smoking together), other cardiac disease $16.28 \%$, condition after myocardial infarction $27.8 \%$ (NYHA II 41\%, NYHA III 56.8\%, NYHA IV 2.2\%).

Results. The greatest problems were in the area of physical activity, sleep and fatigue, the least were in the area of chest pain and blood circulation. The greatest self-care agency was shown in the area of managing problems with physical activities and sleep, the lowest in the area of liquid intake and output. In the patients' subjective opinion, fatigue and sleep problems had the greatest impact on the quality of life.

There were no substantial differences in either area based on gender.

Conclusions. The data can serve as a foundation for modifying the extent and structure of patient education for more comprehensive and more effective out-patient treatment of HF.
\end{abstract}

Key words: self-care, self-management, self-care deficit theory, heart failure, education

Received: August 23, 2012; Accepted with revision: June 4, 2013; Available online: June 12, 2013 http://dx.doi.org/10.5507/bp.2013.044

anstitute of Health Care Studies, Faculty of Humanities, Tomas Bata University Zlin, Czech Republic

${ }^{b}$ Department of Internal Medicine I - Cardiology, University Hospital Olomouc and Faculty of Medicine and Dentistry, Palacky University Olomouc

'Department of Nursing, Faculty of Health Sciences, Palacky University Olomouc

${ }^{d}$ Department of Medical Biophysics, Faculty of Medicine and Dentistry, Palacky University Olomouc

Corresponding author: Renata Halmo, e-mail: renata.halmo@gmail.com

\section{INTRODUCTION}

Chronic heart failure (HF) is ranked with the cardiovascular epidemics of the $21^{\text {st }}$ century. Apart from adequate treatment, developing self-care and integrating the health issues consequent to HF problems into the patients' ordinary lives play an important role in the longterm care of these patients.

Self-care is applied primarily to patients with chronic illnesses, e.g. diabetes mellitus, arthritis, asthma etc. The extent of self-care depends on the character and stage of the illness, e.g. diabetic patients, in compliance with medical treatment, have to be able to prevent the complications and to regulate their glycaemia efficiently. HF patients are exposed to a number of problems and they have to learn how to integrate them efficiently into their ordinary lives.

Self-care stems from the demands laid on a given person in a given situation on the one hand and the ability of the individual to perform self-care operations on the other. If this relation is not balanced (the demands exceed the capabilities), the individual needs nursing care ${ }^{1,2}$.

The concepts of D.E. Orem's self-care theory were used to define the need for care in these patients (see Table 1 and 2) and with the focus on patient self-care support. The central idea of Orem's self-care deficit nursing theory is deliberate human action which is carried out by an individual to maintain certain material and health conditions to sustain life and personal development. Orem's concept of self-care operations ${ }^{1,2}$ consists of three levels - estimative, transitive and productive, i.e. an individual must have sufficient information to be able to choose the right alternative of action, choose appropriate steps for performing it and assess whether and to what extent they are able to perform the action and finally perform $\mathrm{it}^{3-5}$. Both concepts self-care and self-management, involve components of cognition, decision-making and adequate action.

The concept of HF patient self-management was defined by Jaarsma ${ }^{5,6}$ as the process of cognitive decision making related to the response to HF symptoms. HF patients have to be able to assess the symptoms, e.g. dyspnoea, chest pain, palpitations, excretion problems, edema and body weight, fatigue and decrease in physical activity and know how these develop. They should also 
know about the causes of the illness as well as the treatment strategy and risk factors, and master the techniques to manage the problems.

The concept "chronic care model", within the context of enhancing the patients' self-care agency is also found. This model attempts to develop the patients' psychological and cognitive abilities in such a way that they can act as their own primary care providers ${ }^{7}$.

There are tendencies increasing worldwide to involve chronic patients in self-care and to utilize their potential to the maximum. This also results from the increasing morbidity and mortality in chronic patients reported in highly-developed countries. According to Bodenheimer, this results in a new paradigm for these patients: "People with chronic conditions are their own principal caregivers." This paradigm assumes that while professionals are specialists in the illness, the patients are specialists in their own lives with the illness ${ }^{8}$.

If we apply the above principles to HF patients, we find that patients with this diagnosis should know and follow a number of regulations, restrictions, and also incorporate them into their everyday lives to sustain a certain quality of life by performing self-care, and to prevent impending complications due to HF. The specialist, a specialized nurse in this case, can help patients obtain adequate knowledge, acquire the ability to make correct decisions while managing their problems, and teach them to carry out efficient actions for adequate functioning. However, nurses, too, have to know how to work systematically, their steps should be grounded in a nursing theory, in this case Orem's self-care deficit nursing theory (SCDNT). On the one hand, a nurse has to be thoroughly acquainted with the illness they help the patients manage (its causes, symptoms, complications and treatment strategies) and has to be able to define the need for care and demands put on the patient in such a new situation. On the other hand, they have to be able to assess the patient's self-care system, analyse the causes of its deficiencies, and define what the patient has to learn to be able to manage the new situation. This is considered a starting point for defining the level of support. It involves a wholly compensatory nursing system in which the nurse (or the family) have to take over the patient care interventions, or a partly compensatory system in which the patient is able to perform certain self-care actions only, and also a supportive-educative system in which the nurse educates and supports the patient with the aim of him/her being able to perform effective self-care ${ }^{1,2}$.

The increasing occurrence of HF in the population is related to age and also to the management of urgent conditions, e.g. myocardial infarction. The concept of HF characterizes the condition when the heart is not able to meet tissue metabolic requirements, it fails to function as a pump and congestion of blood occurs in the systemic or pulmonary veins ${ }^{9}$.

Typical clinical symptoms of heart failure are dyspnoea, cough, fatigue, peripheral edema, sweating, nycturia, oliguria, insomnia, nausea, vomiting, obstipation, tachycardia and stenocardia in ischemic heart disease. To assess the functional severity of HF, the NYHA (New
York Heart Association) classification I-IV is used which is modified into the A-D classification in contemporary American guidelines. The cause of HF should always be stated since there is a set of symptoms which may vary and adequate treatment and patient care should thus be chosen accordingly ${ }^{10}$.

In a heart-failure outpatient clinic, it is primarily the application of a supportive-educative nursing system which makes it possible for patients to better manage their problems and, if possible, sustain an optimal quality of life.

The central and dominant factor of quality of life is to reach personal life goals through self-management. The quality of life in this sense is understood according to Krrivohlavý ${ }^{11}$, i.e. in a personal level, as a subjective assessment of the health condition by the patients themselves based on their own values and the influence of managing problems on realizing their personal plans and goals.

\section{Project stages and tasks}

This paper presents a pilot project designed in cooperation with the heart-failure outpatient clinic at the Department of Internal Medicine I - Cardiology at University Hospital Olomouc with the title "Increasing the level of self-care agency in patients with heart failure." To achieve the main objective, the following project stages and partial objectives were planned.

\section{Project stages:}

1. Defining therapeutic self-care demand for heart failure patients, which served as the basis for creating an assessment tool (questionnaire) and educational programmes.

2. Creation of the questionnaire to determine the level of the patients' problems and abilities (level of self-care) to manage the problems connected with HF.

In relation to the questionnaire, the following tasks were, to determine:

a) T 1 - which problems associated with HF represented the greatest burden to the patients.

b) $\mathrm{T} 2$ - the level of self-care for managing their problems.

c) T 3 - how HF patients perceive the impact of the problems on the quality of their lives.

d) T 4 - whether there was a gender difference for either variable.

The stages of the project planned in the future: creation of educational programmes according to the therapeutic self-care demand, targeted education of the patients, mapping of the level of problem and level of self-care in these patients.

\section{METHODS}

The first project stage was preceded by thorough study of the literature on SCDNT and heart failure. The knowledge was analyzed, compared and this was followed by deducing the effect of HF illness on self-care requisites 
Table 1. Therapeutic self-care demand with chronic heart failure patients.

\begin{tabular}{|c|c|}
\hline $\begin{array}{l}\text { Universal self-care requisites } \\
\left(\mathrm{Orem}^{1,2}\right)\end{array}$ & $\begin{array}{l}\text { - Symptoms } \\
\text { - HF patient's self-care capabilities required to help regulate the problem (and represent educational } \\
\text { goals for the nurse) }\end{array}$ \\
\hline $\begin{array}{l}\text { 1. Maintaining a sufficient } \\
\text { intake of air }\end{array}$ & $\begin{array}{l}\text { - Dyspnoea under strain, dyspnoea in rest, cyanosis. } \\
\text { - Impulse to cough, cough, or frothy sputum expectoration. } \\
\text { - The patient masters the techniques which help reduce dyspnoea and make breathing easier. } \\
\text { - The patient knows about the harmful effects of nicotine and makes efforts to eliminate it. } \\
\text { - The patient knows why he/she has to avoid extreme heights and temperatures and observes it. } \\
\text { - etc. }\end{array}$ \\
\hline $\begin{array}{l}\text { 2. Maintaining a sufficient } \\
\text { intake of water }\end{array}$ & $\begin{array}{l}\text { - Lower limbs edema, position-dependent edema. } \\
\text { - Increased volume of body fluids. } \\
\text { - The patient can recognize the symptoms of retaining fluids in the body. } \\
\text { - The patient knows when and how to reduce the intake of water. } \\
\text { - The patient consumes only recommended drinks - mineral water rich in magnesium and table } \\
\text { water (reducing coffee and alcohol intake). } \\
\text { - The patient knows why and how to check the body weight and does so. } \\
\text { - etc. }\end{array}$ \\
\hline $\begin{array}{l}\text { 3. Maintaining a sufficient } \\
\text { intake of food }\end{array}$ & $\begin{array}{l}\text { - Nausea, lack of appetite. } \\
\text { - Overweight, ignorance of BMI. } \\
\text { - Ignorance of dietary measures. } \\
\text { - The patient knows his/her optimal body weight and makes efforts to keep it. } \\
\text { - Making efforts to reduce body weight in obese patients. } \\
\text { - The patients knows why and how to reduce the } \mathrm{NaCl} \text { intake in food (down to } 4-5 \mathrm{gr} / \mathrm{d} \text { ). } \\
\text { - The patient knows why and how to reduce the intake of foods high in cholesterol and does so. } \\
\text { - etc. }\end{array}$ \\
\hline $\begin{array}{l}\text { 4. Providing care associated } \\
\text { with eliminative processes } \\
\text { and excrements }\end{array}$ & $\begin{array}{l}\text { - Excessive urination, mostly at night (nycturia). } \\
\text { - Excessive urination while taking a diuretic. } \\
\text { - Constipation. } \\
\text { - The patient knows and carries out actions to reduce the retention of fluids in the body. } \\
\text { - The patient knows and carries out actions for regular elimination. } \\
\text { - etc. }\end{array}$ \\
\hline $\begin{array}{l}\text { 5. Maintaining a balance } \\
\text { between activity and rest }\end{array}$ & $\begin{array}{l}\text { - Anginous pain, tachycardia. } \\
\text { - Reduced tolerance of physical activity. } \\
\text { - Sleep disorders. } \\
\text { - Fatigue. } \\
\text { - The patient knows and performs adequate physical activity 3-5 times a week for 20-30 min. } \\
\text { (dynamic activity with pulse rate check). } \\
\text { - The patient knows their limits of body burden. } \\
\text { - The patient knows how to prevent fatigue and how to improve the quality of sleep. } \\
\text { - etc. }\end{array}$ \\
\hline $\begin{array}{l}\text { 6. Maintaining a balance } \\
\text { between solitude and } \\
\text { social interaction }\end{array}$ & $\begin{array}{l}\text { - Reduced social activity, fatigue. } \\
\text { - The family knows how to help the patient maintain social contacts. } \\
\text { - etc. }\end{array}$ \\
\hline $\begin{array}{l}\text { 7. Preventing hazards } \\
\text { to human life, human } \\
\text { functioning and psychical } \\
\text { and physical well-being }\end{array}$ & $\begin{array}{l}\text { - Increased risk of infection. } \\
\text { - Risk of physical and psychical overload due to incorrect assessment of one's own potential. } \\
\text { - The patient knows about the risks related to the illness development. } \\
\text { - The patient knows about the risks related to the treatment. } \\
\text { - The patient knows how to prevent these risks. } \\
\text { - etc. }\end{array}$ \\
\hline $\begin{array}{l}\text { 8. Promotion of human } \\
\text { functioning and } \\
\text { developing within social } \\
\text { groups in accordance with } \\
\text { human potential, known } \\
\text { human limitations and } \\
\text { the human desire to be } \\
\text { normal. }\end{array}$ & $\begin{array}{l}\text { - Fear of isolation resulting from reduced tolerance of activity. } \\
\text { - Psychical discomfort and reduced ability to pursuecertain hobbies. } \\
\text { - Psychological discomfort related to the necessity to follow medical treatment. } \\
\text { - The patient knows and applies methods to preserve his/her psychological balance. } \\
\text { - etc. }\end{array}$ \\
\hline
\end{tabular}


Table 2. Therapeutic self-care demand with chronic heart failure patients.

Health-deviation self-care requisites $\left(\right.$ Orem $\left.^{1,2}\right)$
- Self-care requisites for HF patients (self-care agency)
1. Seeking and securing appropriate medical assistance

- The patient knows the diagnostic methods and treatment strategies, including contacts to the specialists.

- The patient knows the medications which are totally unsuitable for HF.

- etc.

- The patient knows the basic causes and symptoms of the illness.

- The patient is able to recognize the symptoms of aggravation and respond adequately to it.

- etc.

3. Effectively carrying out medically prescribed (diagnostic, therapeutic and rehabilitative) measures
- The patient knows and follows daily routine measures related to water and food intake and physical activity.

- The patient keeps to the check-up dates at the doctor's.

- etc.
4. Being aware of, attending to and regulating the discomforting (or deleterious) effects of medical care measures
- The patient knows invasive examination methods and the potential complications.

- The patient knows the prescribed medications and their side-effects and adverse effects.

- etc.
5. Modifying the self-concept (and self-image) in accepting oneself as being in a particular state of health and in need of specific form of health care
- The patient is able to overcome the feeling of not being self-sufficient / inability to manage the situation.

- etc.
6. Learning to live with the effects of pathologic conditions and the effects of medial (diagnostic and) treatment measures in a life-style that promotes continued personal development.
- The patient accepts the course of the illness and treatment and their integration into common life.

- The patient is able to assess realistically their own potential and to set feasible goals.

- The patient knows their limitations in relation to everyday activities (e.g. driving a motor vehicle with NYHA IV etc.)

- etc. and deriving problems that the patients would have to manage in a given situation (situational problem areas).

The second stage was based on deductive conclusions from the first stage while creating an assessment tool for the problems of HF patients and self-care agency level as a questionnaire created in cooperation with employees of the heart-failure outpatient clinic at the Department of Internal Medicine I - Cardiology at the University Hospital in Olomouc and the Department of Medical Biophysics, Palacky University Olomouc. The questionnaire was created according to situational problem areas and divided into 7 areas with closed format questions. In each area, the level of the patients' problems and level of self-care actions performed to manage given problems were mapped. The responses were given points and the point score was processed by statistical software SPSS, version 15, SPSS Inc. Chicago, USA.Non parametric tests, Kruskal Wallis and Mann Whitney were used to determine differences.
The questionnaire was distributed to:

Patients diagnosed with HF.

NYHA II, III and IV patients.

Men and women.

Patients treated in the heart-failure outpatient clinic.

They were distributed by the nurses in the heart-failure outpatient clinic in the period 2007-2009. The patients completed the questionnaire in the waiting room and put the completed questionnaire in a sealed box. This was voluntary and anonymous.

Characteristics of the group of 47 patients ( 14 women $=29.78 \%$ ) suffering from chronic heart failure: average age 68 years, average BMI 29.4, treated according to heart failure guidelines, resynchronization therapy $21 \%$.

Comorbidities in the personal history: hypertension $69.8 \%$, diabetes mellitus $25.6 \%$, coronary artery disease $46.5 \%$ (including $27.8 \%$ after myocardial infarction), dilated cardiomyopathy $46.5 \%$, obesity $46.5 \%$, smoking history 
$39.5 \%$ (present and past smoking together), other cardiac disease $16.28 \%$ (valvular heart disease, tachyarrhythmias, Fabry disease).

Functional heart failure classification: $41 \%$ out of 47 (100\%) respondents fell into NYHA Class II, 56.8\% fell into NYHA Class III and 2.2\% into NYHA Class IV.

\section{RESULTS}

The relation of HF to self-care requisites was defined (see Table 1 and 2) and shows the problems the patients have to face and competencies that could help them regulate their problems. The list of all self-care actions used for the regulation of the problems associated with $\mathrm{HF}$ is called therapeutic self-care demand.

The above mentioned relation was used to derive the deficit in the actions taken while managing the problems which may be expected in HF patients and which were defined in the form of situational problem areas (i.e. problems expected in a given situation) ( ref. $^{5,12,13}$ ).

1. Breathing problems.

2. Problems with chest pain and blood circulation.

3. Problems with fluid intake and output, nutritional problems.

4. Problems with physical activity and sleep.

5. Psycho-social problems.

6. Medicamentous therapy.

7. Risk factors.

8. Cardiac illness, knowledge of its causes, symptoms and treatment strategies (this area relates to all the above mentioned areas and was not included in the questionnaire as a separate area).

Relevant self-care or dependent-care, in the case the care is provided by another person, e.g. family member, competencies necessary for the correction of the problem were defined for each of the above mentioned problem areas. The set of all competencies the HF patient has to acquire to be able to effectively manage the given situation is called a therapeutic self-care demand. This self-care demand was elaborated in detail and became the starting point for the questionnaire and also provided the basis for creating educational programmes. A brief summary is presented in Tables 1 and 2.

\section{The questionnaire results}

The results of the questionnaire research map the patients' problems and an adequate level of self-care.

47 patients attending the heart-failure outpatient clinic participated in the questionnaire research. Some patients did not complete all fields and explains why some of the indicators were analyzed on 31-47 completed data fields for a particular item.
Table 3. Anthropometric data of the patients.

\begin{tabular}{lcccc}
\hline Group & Age & Weight & Height & BMI \\
\hline $\mathrm{N}$ & 40 & 32 & 34 & 32 \\
Minimum & 46 & 61 & 150 & 20.9 \\
Maximum & 88 & 135 & 192 & 40.8 \\
Median & 70 & 85 & 174 & 29.185 \\
Mean & 68.33 & 88.47 & 172.32 & 29.422 \\
Std. Deviation & 11.663 & 18.589 & 10.834 & 4.6244 \\
\hline
\end{tabular}

Altogether $66 \%$ of patients knew the reason leading to $\mathrm{HF}$, in $27.8 \%$ of cases it was the condition after MI. $51.1 \%$ of the respondents showed increased blood pressure; $27.7 \%$ stress and $44.7 \%$ obesity. The respondents indicated the following symptoms as commonest, in order of frequency: dyspnoea in $68.1 \%$; fatigue in $46.8 \%$ and nycturia in $40.4 \%$.

The Tasks 1 and 2 (T1, T2) of the questionnaire research were to find out which problems represent the greatest burden for the HF patients, and what level of self-care necessary for managing these problems the patients reported.

The mapped areas correspond to the above defined problem areas. There were 7 areas in total: breathing; blood circulation and chest pain; water and food intake and excretion; activity and sleep; medicamentous therapy; risk factors and psycho-social problems. In each of these areas, the problems and self-care actions the patients reported were mapped. In the area of water intake and output, for example, the problems such as putting on weight, lower limb edema, nycturia, and their occurrence, level etc. were mapped. The patients' responses - 'always', 'sometimes', and 'never' - corresponded to the points 2, 1 and 0 respectively. The points were added together for all the areas and the higher the total score was, the higher the level of problem. According to the problems, the self-care actions were mapped, e.g. weighing every day, knowledge of recommended volume of water intake, knowledge and consumption of appropriate drinks, measuring calf circumference etc. For the patients' answers to the mapped parameters - 'always', 'sometimes' and 'never' - corresponded to the number of points - 0, 1 and 2 points. A low total score reflected high level of self-care and vice versa. The scores of all the respondents were calculated for each of the areas to compare the level of problems to the level of self-care. The higher the score of a separate problem, the higher the level of problem (see Table 4), and the higher the score for separate self-care areas, the lower the level of self-care (see Table 4).

The Kruskal Wallis non parametric test confirmed significant differences between the levels of problems and the levels of self-care. Table 4 shows these data. 
Table 4. The level of problems and the level of self-care in HF patients.

\begin{tabular}{lcc}
\hline Observed areas & $\begin{array}{c}\text { Level of } \\
\text { problems }\end{array}$ & $\begin{array}{c}\text { Level of } \\
\text { self-care }\end{array}$ \\
\hline Breathing & 3.88 & 4.12 \\
Blood circulation and chest pain & 2.47 & 4.35 \\
Food and water intake and output & 4.27 & 4.55 \\
Sleep, fatigue and physical activity & 5.95 & 2.85 \\
Psycho-social area & 4.27 & 4.02 \\
Medicamentous therapy & 3.15 & 4.39 \\
Risk factors & 4 & 3.73 \\
\hline
\end{tabular}

The HF patients reported most problems with physical activity and sleep and the lowest level of self-care were stated to be in the area of water and food intake and output.

The third task of the questionnaire research (T3) was to find out how the patients perceive the impact of the problems on their quality of life. The respondents were asked to indicate the impact of each given problem on quality of life (QL) on the 3 point scale with the numbers indicating the following levels: 1 - QL is not affected at all by the problems, 2 - QL is affected in part, $3-\mathrm{QL}$ is markedly affected.

In the first place, the respondents' quality of life is affected by the problems with physical activity and sleep: out of 31 (100\%) patients who responded to this questionnaire item, 7 (21.9\%) stated that this problem markedly affects their quality of life, $20(62.5 \%)$ of the patients reported that this problem affected their quality of life in part and only 5 patients $(15.6 \%)$ were not aware of these problems.

In the second place, the problem with breathing affected the respondents' QL: out of $36(100 \%)$ patients who responded to this item, $13(36.1 \%)$ stated that breathing problems markedly affected their quality of life, $15(41.7 \%)$ reported that this problem affected their quality of life in part, and 8 patients $(22.2 \%)$ were not aware of these problems.

In the third place, the respondents reported the problems with food and water intake and output as affecting their QL most: out of 31 (100\%) patients who responded to this questionnaire item, $10(32.3 \%)$ stated that this problem markedly affected their quality of life, 17 (54.8\%) of the patients reported that this problem affected their quality of life in part and only 4 patients $(12.9 \%)$ were not aware of these problems.

Next, there were psycho-social problems in fourth place, chest pain and blood circulation in fifth place, problems with medicamentous therapy in sixth place and risk factors in the last, seventh place.

The fourth task (T4) of the questionnaire research was to find out whether there were gender differences in level of problems and levels of self-care. The non-parametric Mann-Whitney tests showed no significant differences between HF males and females, either in the observed areas of problems, or the levels of self-care.

\section{DISCUSSION}

Heart failure ranks with the cardio-vascular pandemics of the $21^{\text {st }}$ century. It is reported that half of patients with a diagnosis of HF die within 4 years and $50 \%$ of the patients with severe stage HF die in one year ${ }^{10}$.

The results of the Framingham Study contributed significantly to understanding the causal relations in the development of heart failure. This extensive study which has been collecting data since 1948, turned attention to factors that affect negatively the cardiovascular system and thus are called risk factors, e.g. heredity, obesity, low physical activity, alcohol and nicotine consumption, increased salt and fat levels in food, psycho-social factors etc. ${ }^{14}$. Based on these facts, care for HF patients concentrates not only on treatment but also on patient support while ensuring effective regulation of the risk factors and integration of the problems related to HF into everyday life ${ }^{15}$. Similar efforts are documented in the National Cardiovascular Programme created by the Czech Society of Cardiology which states that one of its objectives is that each individual is responsible for his/her own health and has the right to receive complete information concerning their health status and measures advisable for improving or sustaining it, so that they can make decisions. It is self evident that the question of the patients' participation in their own health care, especially with chronically ill patients, attracts the attention of specialists all over the world. For this purpose, various scales were developed, e.g. „Heart Failure Self-care Behaviour Scale" with 12 items based on a Likert scale. The items focus on finding out whether a HF patient performs the actions which help them monitor the symptoms such as dyspnoea, water retention and related changes in body weight etc., as well as the regulation and correction of influenceable risk factors ${ }^{6}$.

Based on this experience, we decided to use D.E. Orem's self-care deficit theory in this project since it emphasises deliberate human action and tries to maximally utilize the patient's potential for self-care. We related the effects of HF illness to Orem's self-care requisites and derived the following situational problem areas which the patient has to learn to manage and integrate into everyday life: breathing, chest pain and blood circulation, water intake and output, nutrition, physical activity and sleep, psycho-social problems, medicamentous therapy, risk factors, knowledge of the illness (its causes, symptoms and treatment strategies). Next, we elaborated the therapeutic self-care demand for the HF patients, i.e. care requirements related to the illness which a nurse should expect and be able to deal with, and, if need be, teach the patient to manage (see Tables 1 and 2).

The following step was aimed at creating and testing an assessment tool (questionnaire) for HF patients which could capture the level of their problems and the level of self-care in managing these problems, and also contribute to finding out the impact of these problems on the patients' quality of life. In this respect, our goal differed from other projects and studies carried out, as we tried to relate the levels of the patient's problems on the one hand 
and the level of their self-care actions taken to regulate the problems on the other hand.

The respondents showed the highest level of problems in the area of physical activity and sleep, which corresponds to the data in the Guidelines of the Czech Society of Cardiology (2011) which lists fatigue and inefficiency as the most frequent symptoms of HF. The cause of these symptoms is both insufficient oxygen and nutrients supply to the tissues and metabolic changes in tissues, mainly in skeletal muscles. Although dyspnoea is listed as the second most frequent symptom in the guidelines, the patients reported problems with breathing in the fifth place, after the problems with physical activity and sleep, water and food intake and output, psycho-social problems and problems related to risk factors (see Table 4 ). This could be explained by the fact that the group of respondents included NYHA II-IV patients and $41 \%$ of the respondents belong to NYHA II which is characterized by less limited physical activity, and although everyday common activities cause exhaustion, dyspnoea results mostly from physical effort. In NYHA IV patients, dyspnoea occurs during any physical activity, and often even at rest. On the other hand, it is obvious that fatigue and physical activity and problems with breathing are perceived very intensively by the respondents from their subjective point of view as they affect their quality of life most markedly. Insufficient level of self-care shown by the respondents (see Table 4) may also contribute to these results.

\section{CONCLUSIONS}

Specialized HF nurses are an important part of the multidisciplinary team covering management programmes for patients in heart failure clinics. The material described here provides them with a tool for assessing the HF patients' self-care system and identifying areas where it fails. The structured survey itself, assists the nursing team with the necessary information to support these patients. Overall, this approach to HF management can contribute to lowering hospital readmissions of HF patients.

\section{ACKNOWLEDGEMENT}

Authorship contributions: RH: literature search; RH, JG: manuscript writing; RH: study design, data collection and interpretation; RH, JG: data analysis; KL, DG: statistical analysis, figures; RH, JG: final approval.

Conflict of interest statement: None declared.

\section{REFERENCES}

1. Orem DE.: Strukturkonzepte der Pflegepraxis. Berlin, Wiesbaden: Ullstein Mosby GmbH \& Co. KG; 1997.

2. Orem DE.: Nursing concepts of practice. 6th ed.St. Louis, Missouri: Mosby, Inc.; 2001

3. Bekel G, Halmo R. Teorie deficitu sebepéče, 1. vyd. Olomouc: Univerzita Palackého v Olomouci; 2004.

4. Bekel G. Die Selbstpflegedefizit - Theorie von Dorothea E.Orem. In Holoch, Gehrke, Knigge - Demal, Zoller. Kinderkrankenpflege, Bern, Göttingen, Toronto, Seattle: Verlag Hans Huber; 1999. p.48 - 56.

5. Halmo R. Užití teorie deficitu sebepéče v kardiologii. In Čáp E, Žiaková J, Martin K. Ošetrovateĺstvo teória, výskum a vzdelavanie. JLF UK a LF UP; 2007. p.115 - 125.

6. Jaarsma T, Störnberg A, Martensson J, Draup K. Development and testing of the European Heart Failure Self-care Behaviour Scale. The Eur J Heart Fail 2003;(5):363-70.

7. Shuldham C, Theaker C, Jaarsma T, Cowie MR. Evaluation of the European Heart Failure Self-care Behaviour Scale in a United Kingdom population. J Adv Nurs 2007; 60(1):87-95.

8. Bodenheimer T, Lorig K, Holman, H., Grumbach, K. Patient Selfmanagement of Chronic Disease in Primary Care. JAMA 2002; 288(19):2469-75.

9. Lukl J. Klinická kardiologie stručně. 1. vyd. Olomouc: Univerzita Palackého v Olomouci; 2004.

10. Špinar J, Vítovec J, Hradec J, Málek I, Meluzín J, Špinarová L, Hošková L, Hegarová M, Ludka O, Táborský M. Doporučený postup České kardiologické společnosti pro diagnostiku a léčbu chronického srdečního selhání, 2011. Supplementum Cor et Vasa 2012;54:e11334.

11. Křivohlavý J. Psychologie nemoci. Praha: Grada;2001.

12. Hrbáčková M. Sebepéče u nemocných s chronickým srdečním selháním. Diplomová práce, Olomouc: Ústav teorie a praxe ošetřovatelství, LF UP; 2008.

13. Stržínková, M., Užití teorie deficitu sebepéče u pacientů s ICHS. Diplomová práce, Olomouc: Ústav teorie a praxe ošetřovatelství, LF UP; 2005.

14. Kannel WB. Incidence and epidemiology of heart failure. Heart Fail Rev 2000;5(2):167-73.

15. Jaarsma T, Halfens R, Senten M, Huijer H, Dracuo K. Developing a supportive-educative program for patients with advanced heart failure within Orem's general theory of nursing. Nurs Sci Q 1998; 11(2):79-85. 